\title{
Psikolojik Esneklik Ölçeği: Uyarlama, Geçerlik ve Güvenirlik Çalışması
}

\section{Psychological Flexibility Scale: Adaptation, Validity and Reliability Study}

\author{
Sena KARAKUŞ*, Sinem Evin AKBAY**
}

\begin{abstract}
Öz: Bu çalışmanın amacı bireylerin psikolojik esnekliklerini ölçen Psikolojik Esneklik Ölçeğinin Türkçe forumunun psikometrik özelliklerini incelemektir. Psikolojik Esneklik Ölçeği, Francis, Dawson ve GolijaniMoghaddam (2016) tarafından geliştirilmiştir. Çalışma, 310 yetişkin bireyin katılımıyla yürütülmüştür. SPSS 22.0 paket programı ile yapılan açımlayıcı faktör analizine göre 28 maddeden ve beș boyuttan oluşan modelin iyi uyum değerlerine sahip olduğu değerlendirilmiştir $(\mathrm{KMO}=0.789 ; \mathrm{X} 2=3096.080 ; \mathrm{p}=0.00)$. Ölçeğin faktör yükleri .47 ile .81 arasında sıralanmaktadır. Ölçek varyansın \%60'ını açıklamaktadır. Ölçeğin Cronbach Alfa iç tutarlılık güvenirlik katsayısı .79 olarak bulunmuştur. Elde edilen veriler, uyarlaması yapılan Psikolojik Esneklik Ölçeği’nin Türkiye'deki yetişkin bireylerin psikolojik esnekliklerinin ölçülmesinde geçerli ve güvenilir bir ölçme aracı olduğunu göstermiştir.
\end{abstract}

Anahtar Kelimeler: Psikolojik esneklik, ölçek uyarlama, geçerlik, güvenirlik

\begin{abstract}
The purpose of this study is to adapt Psychological Flexibility Scale into Turkish culture and to examine the validity and reliability of the scale. The Psychological Flexibility Scale is developed by Francis, Dawson ve Golijani-Moghaddam (2016). The study was conducted with the participation of 310 adult individuals. According to exploratory factor analysis used by SPSS 22., it is evaluated that the model consisting of five dimension with 28 items, has high compliance values $(\mathrm{KMO}=0.789 ; \mathrm{X} 2=3096.080 ; \mathrm{p}=0.00)$. The factor loadings of the scale range from .48 and .82 . According to the exploratory factor analysis result, it explained .60 of the scale variance consisting of one dimension. Cronbach's Alpha internal consistency reliability coefficient of the scale was found as .79.The result indicates that adapted Psychological Flexibility Scale is a valid and reliable measurement tool in measuring psychological flexibility of the adult individuals in Turkey.
\end{abstract}

Keywords: Psychological flexibility, scale adaptation, exploratory factor analysis

\section{Giriş}

Kabul ve Kararlı1ık yaklaşımını temel alan psikolojik danışma yaklaşımı günümüzde yaygın bir şekilde kullanılmaya başlanmıştır. Kişinin geçmiş ve geleceğe takılı kalmak yerine anı yaşamaya çalışmasını, duygu, düşünce ve davranışlarının farkında olmasını, kabullenmesini amaçlayan Kabul ve Kararlılık temelli yaklaşımlarda en önemli kavramlardan birisi psikolojik esnekliktir. Frankl (2013), hayatın acı verici koşullar altında bile anlamlı olabileceğini ve insanların kendilerini acıya karşı koruyabileceğini ifade eder. Benzer şekilde, Kabul ve Kararlılık yaklaşımında şu anda yaşananlar ne olursa olsun, bireylerin bunu sıkıntı ve acı karşısında olduğu gibi kabul etmeleri gerektiği ve bu deneyimlerden haberdar olarak yaşamı kucaklamaları gerektiği vurgulanmaktadır (Terzi ve Tekinalp, 2013). Hayatı bir bütün olarak olumlu ve olumsuz yönleriyle bütünleştiren zihinsel ve duygusal kabuller, bireyin yaşamının kontrol edilemeyen taraflarına karşı kişisel gücünü arttırır (Wong, 2015). Kabul ve Kararlılık yaklaşımının da temel kavramlarından biri olan ve bu anlatılanları karşılayan kavram ise 'psikolojik esneklik'tir (Yavuz, 2015).

Psikolojik esneklik, bireyin geçmiş ve geleceğe takılı kalmayıp içinde olduğu an ile temas etmesi ve belirlemiş olduğu değerleri doğrultusunda davranışlar gerçekleştirmesidir (Luoma, Hayes ve Walser, 2010). Psikolojik katılık ise bunun tam tersini ifade etmektedir. Kabul ve Kararlılık Terapisi (KKT) psikopatoloji modelini psikolojik katılık altıgenini kullanarak açıklamıştır. Psikolojik esneklik modeli de bu altıgen doğrultusunda oluşturulmuştur (Harris, 2009).

* Öğr. Gör., Mersin Üniversitesi, Eğitim Fakültesi, Mersin-Türkiye, ORCID: 0000-0003-3156-6958, e-posta: karakussena@outlook.com

** Dr. Öğr. Üyesi, Mersin Üniversitesi, Eğitim Fakültesi, Mersin-Türkiye, ORCID: 0000-0001-6189-1896, e-posta: sinemakbay85@gmail.com 


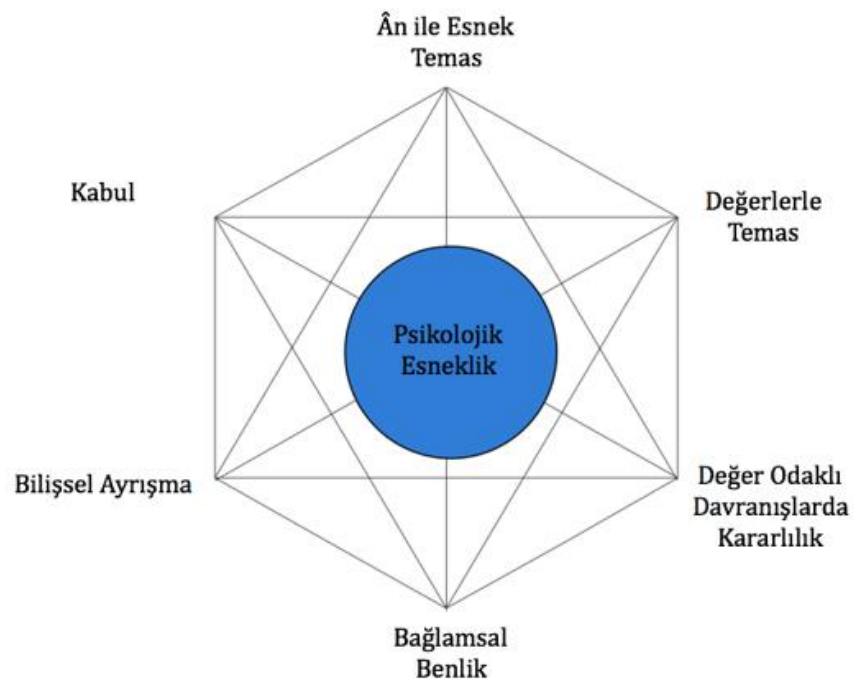

Şekil 1. Psikolojik Esneklik Modeli: KKT Altıgeni (Aktepe, 2016)

Psikolojik esnekliğin de psikolojik katıllğıı zıttı olacak şekilde Kabul, Ayrışma, An'da Olmak, Bağlamsal Benlik, Değerler ve Değerler Doğrultusundaki Davranışlar olmak üzere altı boyutu bulunmaktadır (Luoma, Hayes ve Walser, 2010). Bu boyutların ilk dördü 'kabul ve an'a odaklanma süreçlerini tanımlarken, son dördü değerler doğrultusundaki davranış değişikliğgi ile ilgili süreçlerdir. An'da olmak ve bağlamsal benlik her iki tarafla da ilişkilidir. Altı bileşenin her biri, bir diğeri ile ilişkilendirildiğinde daha anlamlı olmaktadır (Hayes, Levin, Plumb-Vilardaga, Villatte ve Pistorello, 2013).

Kabul boyutu bireye üzüntü ya da acı veren duygu, düşünce ve anılara açık olması anlamına gelmektedir. Birey bu anılarla ya da olaylarla mücadele etmeyi bırakarak kabullenir. Bu bireyin bu olayları sevdiği ya da istediği anlamına gelmemekle birlikte sadece bu olaylara direnmek yerine kendi iç dünyasında yer açtığını göstermektedir (Harris, 2009). Kabul boyutu, terapötik olarak psikolojik katılığın alt boyutu olan yaşantısal kaçınmanın alternatifi olarak düşünülebilir. Örneğin kaygı yaşayan bireyler duygusal olarak herhangi bir direnç göstermeden kabul etmeleri yönünde cesaretlendirilir, bireylere buna yönelik egzersizler yaptırılır (Luoma, Hayes ve Walser, 2010).

Ayrışma bireyin zihnindeki sorun yaratan anılardan, düşüncelerinden bir adım uzaklaşması anlamına gelmektedir. Bireyin aklına gelen düşüncelerle mücadele içinde olması yerine onları önünden geçen araba gibi izlemesi önerilmektedir. Egzersizler de bu doğrultuda planlanıp uygulanmaktadır (Harris, 2009). Geleneksel bilişsel terapiler düşünceyi sorunun kaynağı olarak görmekte ve bu yaklaşım bu yönüyle diğer görüşlerden ayrılmaktadır (Hayes, 2004).

An'da olma bireyin "şimdi ve burada" olma halidir. Birey düşünceleri ile boğuşmakta ve yaşamını "otomatik pilot" gibi sürdürmektedir. Anda olmakla anlatılmak istenen bireyin hem dış hem de iç dünya ile temas edebilmesidir. Birey bu şekilde işlevsiz davranış kalıplarının yerine koyabileceği davranışları fark edebilir. Kendindelik temelli terapilerin tümü bu alanda çalışmaktadırlar (Harris, 2009; Hayes, 2004).

Diğer alt boyut olan bağlamsal benliğin ne anlama geldiğini anlayabilmek için iki ayrı benliği açıklamak gerekmektedir: Düşünen benlik ve gözlemleyen benlik. Düşünen benlik, benliğin inanç, hatıra, hayal ve plan gibi düşünce üzerine yoğunlaşan kısmıdır. Gözlemleyen benlik (KKT literatüründeki adıyla bağlamsal benlik) ise tüm yaşam boyunca beden değişirken, düşünceler, duygular, hayattaki roller değişirken tüm bu değişimlere tanıklık eden, bu değişimleri izleyen ve kendisi hiç değişmeyen benlik parçasıdır. Kişilerin tüm içinde bulunduğu içsel yaşantılarına, acı verici deneyimlerine ve kaygılarına rağmen bu benlik parçalarını fark etmeleri psikolojik esnekliklerini arttırarak değerlerini fark etmelerini kolaylaştırır (Harris, 2009; Hayes, 2004; Luoma, Hayes ve Walser, 2010).

Değerler, kişilerin gündelik yaşamı içerisindeki rutinden uzaklaşarak kendilerine "bu hayatı ne için yaşıyorum?” sorusuna verdikleri cevaplardır (Harris, 2009). Kabul ve Kararlılık yaklaşımına göre 
birey kabul ya da bilişsel ayrışma süreçlerini yerine getirse de değerleri netleşmezse istenilen sonuca ulaşamaz. Bu durum araba kullanmayı bilen bir şoförün nereye gitmek istediğini bilmemesine benzetilebilir.

Değerler doğrultusundaki davranışlar ise Kabul ve Kararlılık yaklaşımına dayalı psikolojik danışmanın en temel hedeflerinden birisidir. Yine araba örneğinden yola çıkacak olursak, sadece araba kullanmayı ve gidilecek yolu bilmek işe yaramaz, yola çıkıldığ zaman bu bilgiler anlamlı olur. Alıştırma (exposure), davranış aktivasyonu, beceri eğitimi gibi geleneksel davranışçı müdahalelerinin tümü psikolojik esneklik modelinin bu bölümünde kullanılabilirler (Harris, 2009).

Psikolojik katılık, bireyin uzun vadeli amaçları ile uyumlu davranışlar sergileyememesine sebep olmaktadır (Yavuz, 2015).

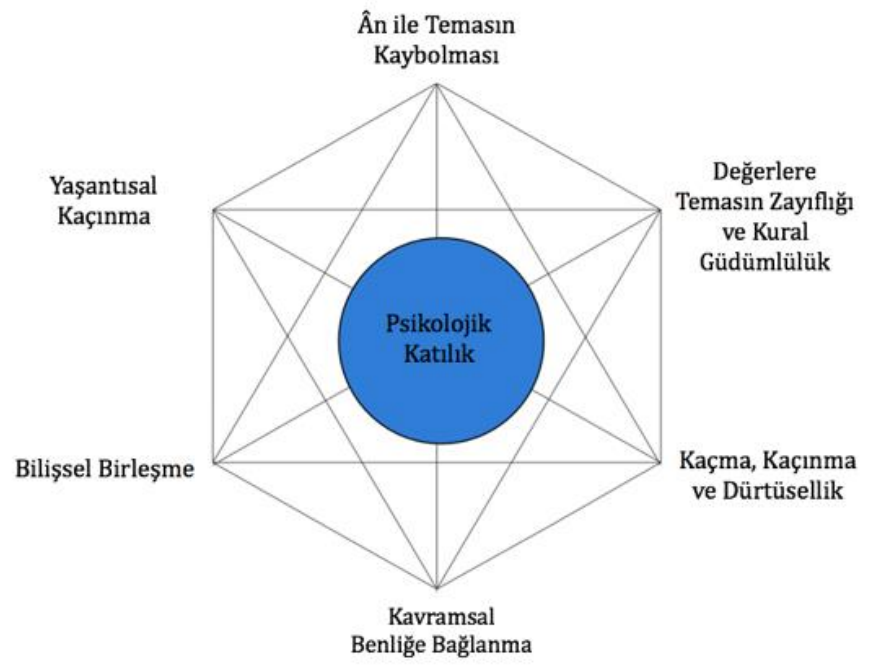

Şekil 2. Psikolojik Katılık Modeli: KKT’nin Psikopatoloji Modeli (Aktepe, 2016)

Psikolojik katılık kavramının 'Yaşantısal Kaçınma, Bilişsel Birleşme, Kavramsal Geçmiş ve Geleceğin Baskınlığı, Kavramsal Benliğe Bağlanma, Değerlerle Kurulan Bağın Zayıflaması ve İşlevsiz Davranış’ olmak üzere 6 adet boyutu vardır. Bu boyutlar birbiriyle ilişkili olduğundan altıgen ağ biçiminde örülü şekilde bulunmaktadır (Luoma, Hayes ve Walser, 2010).

Yaşantısal kaçınma; bireyin istemediği duygu, düşünce, anılarından istemli ve amaçlı bir şekilde kaçma, kaçınma ya da bastırma gibi stratejileri kullanmasıdır. Bu süreç aslında herkesin kullandığı ve çoğu zaman patolojik olarak adlandırılmamaktadır. Örneğin bir yerimiz ağrıdığında ağrı kesici ilaç içmemiz işlevsel yaşantısal kaçınma örneklerinden birisidir. Ancak zaman zaman bu stratejilerin madde bağımlılığında olduğu gibi işlevsiz kullanıldığı ve yaşanılan zorluk ile acıyı arttırdığı görülmektedir. Çünkü bu maddeler kısa vadede bireyin yaşadığı acıyı azaltırken uzun vadede hayattaki değer verdiği alanlardan uzaklaştıracağından daha çok acı çekmesine sebep olabilmektedir. Depresyon ve anksiyete bozuklukları da bu döngüye benzer şekilde açıklanabilmektedir (Harris, 2009).

Bilişsel birleşmede birey düşünceleriyle birleşmiş durumdadır. Bireyin zihni faşizan bir diktatöre benzetilebilir ve birey düşüncelerinin etkisi altındadır. Bireyin kendine yönelik farkındalığı ve şu an ile teması yok denecek kadar azdır. Bu duruma örnek olarak depresyondaki bireyler verilebilir.Çünkü depresyonda olan birey "kötüyüm, hiçbir işe yaramıyorum, hiçbir şey değişmeyecek" gibi düşüncelerle; geçmişinde yaşadığı hayal kırıklığ 1 yaratan olaylarla birleşip kendini sosyal çevresinden ya da keyif aldığı aktivitelerden uzaklaştırır (Harris, 2009). Bir OKB hastasının "ellerimi yıkamazsam, eve mikrop bulaştırıp sevdiklerimin ölümüne sebep olabilirim" düşüncesi sonrası ortaya ç1kan kompülsif eylemleri de tipik bir bilişsel birleşmenin sonucudur (Luoma, Hayes ve Walser, 2010). Sonuç olarak, bilişsel birleşmenin şiddeti ve sıklı̆̆ının artması ile bireyin çevresel uyaranlara göre değil, düşüncelerine göre davranmasına sebep olabilir (Yavuz, 2015).

Kavramsal geçmiş ve geleceğin baskınlığ ; bilişsel birleşme ve yaşantısal kaçınmanın bir sonucu olarak şimdi ve burada olamama; şu ana odaklanamama durumudur.Geçmişte bireye acı veren ve üzüntü yaşamasına sebep olan anılarla aşırı meşgul olma, yapılan ruminasyonlar ya da gelecekte başına 
gelebilecek olaylar ile ilgili yaşanılan kaygı diye tanımlanabilmektedir (Harris, 2009). Bu şekilde birey, yeni davranış denemekten kaçınıp geçmişteki işlevsiz davranış kalıplarını tekrarlayabilir (Luoma, Hayes ve Walser, 2010).

Diğer alt boyut olan kavramsal benliğe bağlanmada her bireyin kim olduğuna dair (isim, cinsiyet, medeni hal, yaş) ve hayatta üstlendiği roller, güçlü- zayıf yönler, sevilen ya da hoşlanılmayan şeyler, hayaller, çekilen acılar, yaşanılan üzüntüler gibi bir hikâyesi vardır. Birey kendi hikâyesiyle birleştiğinde ve sadece kendisinin bu hikâyeden ibaret olduğunu düşündüğünde sorun yaşamaya başlar ve bu durum kavramsal benliğe bağlanma olarak adlandırılmaktadır. Bu duruma bir örnek olarak "Panik atak geçiriyorum" demek yerine "benim panik atağım var" diyen bireyler verilebilir. Çünkü bu bireyler bu hastalığ 2009).

Birey bu düşünceleriyle birleşmesinin ve yaşantısal olarak kaçınmasının sonucu olarak bireyden bireye değişebilen değer alanlarından (aile, arkadaşlık, toplumsal sorumluluk, eğitim, meslek) gittikçe uzaklaşabilmektedir. Bu şekilde hareket eden bireylerde davranış planı yaparken bu alanlardan yararlanamazlar (Harris, 2009).

İşlevsiz davranışlar ise bireyin yaşadığı an ile temasının kesilmesi, değer alanlarından uzak olması, yaşamını anlamlandırabilmesi yerine zorlaştıran davranış kalıplarını kullanmasıdır. Depresyondaki bireylerin günlerinin büyük çoğunluğunu yatarak geçirmeleri, aşırı alkol tüketmeleri, keyif aldıkları bireylerden ve aktivitelerden uzaklaşmaları, intihar girişimleri bu davranışların örnekleridir (Harris, 2009).

Alan yazın incelendiğinde psikolojik esneklik kavramına ilişkin olarak yapıyı tek şekilde inceleyen geliştirilmiş ya da uyarlanmış bir ölçeğe rastlanmamıştır. Ancak Kabul Eylem Formu (Yavuz, Iskin, Ulusoy, Esen ve Burhan, 2014), Freiburg Kendindelik Envanteri (Aktepe, 2016), Bilişsel Kaynaşma/Birleşme Ölçeği (Gillanders ve diğerleri, 2014) gibi ölçeklerin kullanılmasıyla bireylerin psikolojik esnekliklerinin ölçüldüğü çalışmalar bulunmaktadır (Örneğin: Albal, 2019). Bireyler hayatlarını devam ettirirken birtakım problemlerle karşılaşabilmektedir ve bu durumda bireylerin çeşitli olumuz duygular yaşamasına neden olmaktadır. Bireylerin karşılaştı̆̆ 1 durum ya da olaylar karşısında duygularını fark edebilmesi, gerçekçi şekilde değerlendirebilmesi ve olayları açıklama biçimi bireyin yaşam kalitesi ve yaşamdan aldığ1 doyum açısında oldukça önem taşıdığı düşünülmektedir. Duygularının farkında olmayan bireyler yaşamlarında sorumluluk alma, karar verme süreçlerinde de problem yaşamaktadırlar (Gün, 2007; Koçak, 2002). Bu nedenle bu çalışmanın amacı Psikolojik Esneklik Ölçeği'nin Türk kültürüne uyarlama çalışmasının yapılmasıdır.

\section{Yöntem}

Psikolojik Esneklik Ölçeğinin uyarlama sürecinde yapılan çalışmalar aşağıda belirtilmiştir.

\section{Çalışma grubu}

Bu çalışma, 2019 yılında Mersin ilinde yaşayan 310 yetişkin bireyden veri toplanarak yürütülmüsstür. Çalışma grubu, kolay ulaşılabileni örnekleme yolu ile oluşturulmuştur.

\section{Veri toplama aracı}

Psikolojik Esneklik Ölçeği: Psikolojik Esneklik Ölçeği, Francis, Dawson ve Golijani-Moghaddam (2016) tarafından geliştirilmiştir. Yetişkin bireyler için geliştirilmiş olan ölçeğin denemelik formu 37 maddeden oluşmakta ve 7'li Likert tipi değerlendirme ile yapılmaktadır. Ölçeğin nihai hali ise 23 maddeden oluşmaktadır. Bu araştırma kapsamında 37 maddelik denemelik form kullanılmıştır. Orjinal ölçeğin yaşantıya açıklık (10 madde), davranışsal farkındalık (5 madde) ve değerler doğrultusunda yaşama ( 8 madde) olmak üzere üç alt boyutu bulunmaktadır. Orjinal ölçeğin nihai formunda ölçek maddelerinin faktör yükleri .46 ile .77 arasında değişmektedir. Ölçek maddelerinin değerlendirmesinde her alt ölçekten alınan yüksek puanlar bireylerin psikolojik olarak esnek olduklarına işaret etmektedir. Ölçeğin Cronbach $\alpha$ iç tutarlı1ık katsayısı yaşantıya açıklık alt ölçeği için .90, davranışsal farkındalık alt ölçeği için .87 ve değerler doğrultusunda yaşam alt ölçeği için .90 olarak bulunmuştur. Ölçeğin tümü için Cronbach $\alpha$ değeri ise .91 olarak hesaplanmıştır (Francis, Dawson ve Golijani-Moghaddam, 2016). 


\section{İşlem}

Psikolojik Esneklik Ölçeği’nin uyarlama çalışmasını yapabilmek için öncelikle ölçeği geliştiren araştırmacılardan gerekli izinler alınmıştır. Türk kültüründe işleyebilecek maddelerin farklı olabileceği düşüncesiyle yazarların denemelik formu göndermeleri istenmiştir. Bu sebeple 37 maddeden oluşan denemelik form ile ileri çeviri çalışması yapılmıştır. Ölçeğin İngilizce formu, İngilizce ve Türkçe'yi iyi derecede bilen üç dil uzmanı ile altı Rehberlik ve Psikolojik Danışmanlık alan uzmanı tarafından Türkçe'ye çevirisi yapılmıştır. Yapılan çeviriler toplandıktan sonra iki alan uzmanı tarafından tekrardan incelenmiş ve son olarak maddelerin anlaşılırlığı ve cümle yapılarının uygunluğu bir Türkçe dili alan uzmanının görüşü alınarak son haline getirilmiştir. Dil ve kültür geçerliği için uzman değerlendirme formu hazırlanmıştır.İlgili form, on Psikolojik Danışmanlık ve Rehberlik bölümü öğretim üyesine, 2 Ölçme ve Değerlendirme alan uzmanına, 2 Psikoloji bölümü öğretim üyesine, 2 İngiliz dil bilim uzmanına ve 1 Türkçe dili uzmanına verilerek dil uygunluğuna ve kültürel uygunluğa göre 1 ile 5 arasında derecelendirmeleri istenmiştir. Ölçek uyarlama süreci ile ilgili en kritik problemlerden birisi ölçeğin ana dilden farklı bir dil ve kültürde geliştirilmiş olmasıdır. Bu sebepten dolayı sadece madde çevirisi yeterli olmamaktadır. Orjinal ölçekte yer alan bazı kavramlar hedef dilde farklı anlamlar ifade edebilir ya da anlamsal karşılığı olmayabilir (Hambleton ve Patsula, 1999). Bu çeviri sürecinde madde çevirileri sadece mekanik olarak çevrilmemeli ve ölçülen yapı kültürel olarak da değerlednirme sürecinden geçmelidir. Bu şekilde yapıdan kaynaklanan yanlılıklar azaltabilir (Hall, Wilson ve Frenkenfield, 2003). Bu sebeple ölçeğin maddelerini hem dilsel hem de kültürel uygunluk açısından değerlendirilmiştir. Ölçeğin kültürel ve dilsel uygunluklarını ortaya koyabilmek adına kapsam geçerlik oranları hesaplanmıştır.

Dilsel ve kültürel eşdeğerlik çalışmasından sonra 310 yetişkin bireye ölçek uygulanmıştır. Uygulama yaklaşık olarak 10 dakika sürmüştür. Ölçeğin yapı geçerliliğini sınamak amacıyla açımlayıcı faktör analizi yapılmıştır. Güvenirlik analizi için ise Cronbach alfa katsayısı hesaplanmıştır. Araştırmada verilerin analizi SPSS 22 ve Excell programları kullanılarak yapılmıştr.

\section{Bulgular \\ Geçerlilik çalışmaları}

Dilsel ve kültürel eşdeğerlik: Denemelik maddelerin 9 kişi tarafindan Türkçeye çevrildiği; sonrasında araştırmacılar ve Türkçe dil uzmanı tarafindan düzenlenen ve anlaşılırlık için 3 kişiyle yapılan çalışmadan sonra çevirinin nihai halinin dilsel ve kültürel uygunluğunu ortaya koymak amaciyla 18 uzmandan görüş alınmıştır. 5 li derecelendirmeyle alınan uzman görüşlerinden 3 puan ve üstü puan alan maddeler uygun olarak kabul edilirken 1 ve 2 puan alan maddelerin uygunluk göstermediği yönünde değerlendirilmiştir. Alınan uzman görüşlerinden kapsam geçerlik oranları hesaplanmıştır. Elde edilen sonuçlar Tablo 1'de gösterilmektedir.

Tablo 1.

Dilsel ve Kültürel Uygunluk Kapsam Geçerlik Oranları (KGO)

\begin{tabular}{ccc}
\hline Madde No & Dilsel Uygunluk & Kültürel Uygunluk \\
\hline Md1 & 0,889 & 0,889 \\
Md2 & 0,889 & 0,895 \\
Md3 & 0,895 & 0,895 \\
Md4 & 0,895 & 0,895 \\
Md5 & 0,882 & 0,882 \\
Md6 & 0,857 & 0,875 \\
Md7 & 0,895 & 0,895 \\
Md8 & 0,895 & 0,895 \\
Md9 & 0,895 & 0,889 \\
Md10 & 0,895 & 0,895 \\
Md11 & 0,529 & 0,765 \\
Md12 & 0,875 & 0,889 \\
Md13 & 0,889 & 0,895 \\
Md15 & 0,857 & 0,882 \\
Md16 & 0,889 & 0,889 \\
\hline
\end{tabular}




\begin{tabular}{lcc}
\hline Md17 & 0,647 & 0,882 \\
Md18 & 0,765 & 0,882 \\
Md19 & 0,765 & 0,882 \\
Md20 & 0,882 & 0,882 \\
Md21 & 0,895 & 0,895 \\
Md22 & 0,889 & 0,882 \\
Md23 & 0,647 & 0,882 \\
Md24 & 0,882 & 0,889 \\
Md25 & 0,294 & 0,75 \\
Md26 & 0,889 & 0,882 \\
Md27 & 0,882 & 0,882 \\
Md28 & 0,889 & 0,895 \\
Md29 & 0,895 & 0,895 \\
Md30 & 0,647 & 1 \\
Md31 & 0,889 & 0,889 \\
Md32 & 0,895 & 0,895 \\
Md33 & 0,882 & 0,895 \\
Md34 & 0,889 & 0,882 \\
Md35 & 1 & 1 \\
Md37 & 0,882 & 1 \\
& 0,882 & 1 \\
\hline
\end{tabular}

Kapsam geçerliği ile ilgili literatürde kapsam geçerliği oranlarının (KGO)uzman sayısına göre minimum değerleri incelendiğinde 18 uzman sayısına göre olması gereken minimum KGO .42'dir (Veneziano ve Hooper, 1997). Bu bilgi doğrultusunda Tablo 1 incelendiğinde, 25. Maddenin kültürel açıdan uygun olarak değerlendirilirken $(\mathrm{KGO}=0,75)$, dilsel açıdan uygun olmadığı $(\mathrm{KGO}=0,294)$ görülmüştür. İlgili madde çıkarıldığında geri kalan 36 maddenin dilsel uygunluğuna ilişkin kapsam geçerlik oranları 0,529 ile 1 puan arasında değişmekte; kültürel uygunluğa ilişkin kapsam geçerlik oranları da 0,765 ile 1 puan arasında değişmektedir. Minumum değer göz önünde bulundurulduğunda 36 madde hem dilsel hem de kültürel uygunluk bakımından istatistiksel olarak anlamlı olduğu sonucu elde edilmiştir. Ölçeğin yapı geçerliliğine kanıt oluşturmak adına açımlayıcı faktör analizi bu 36 madde üzerinden yapılmıştır. Psikolojik Esneklik Ölçeğinin uyarlama çalışması kapsamında yapılan açımlayıcı faktör analizi sonuçlarına aşağıda yer verilmiştir.

Açımlayıcı faktör analizi (AFA): Ölçeğin Türkçe formu 310 yetişkin bireye uygulanmıştır. SPSS veri girişi tamamlandıktan sonra tekli ve çoklu uç değer analizi yapıldıktan sonra kalan 267 katılımcı ile elde edilen veriler yoluyla açımlayıcı faktör analizi yapılmıştır. Faktör analizi, birbiri ile ilişki içinde olan 'p' adet değişkeni bir araya toplayarak daha az sayıda ilişkisiz ve kavramsal olarak yeni değişkenler (faktörler, boyutlar) bulmayı ve keşfetmeyi amaçlayan çok değişkenli bir istatistiksel tekniktir (Çokluk, Şekercioğlu ve Büyüköztürk, 2014). Kaiser-Meyer-Olkin (KMO) ve Bartlett Sphericity testleri aracıllğıgla verilerin faktör analizine uygunluğu incelenmektedir. .60'dan yüksek olan KMO değeri verilerin faktör analizine uygun olduğunu göstermektedir (Büyüköztürk, 2007). Bu araştırmanın verilerinin faktör analizine uygun olup olmadığını test etmek amacıyla KMO katsayısı ve Bartlett değerine bakılmıştır. Sonuçlar KMO=0.789; X2=3096.080; $\mathrm{p}=0.00$ olduğundan veri setinin faktör analizine uygun olduğu görülmektedir. Araştırmanın faktör analizi orijinal 37 maddelik denemelik form üzerinden yapılmıştır. Yapılan faktör analizi sonucunda ölçeğin orijinal ölçekten farklı olarak beş faktörlü bir yapıda olduğu ve toplam varyansın \%60'ını açıkladığ görülmüştür. Birden fazla faktöre yön veren ve hiçbir faktör yük vermeyen maddeler $(1,6,8,11,13,24,26,37)$ ölçekten çıkarılmış ve yeniden faktör analizi yapılmıştır.Ölçeğin faktör analizi sonuçları aşağıdaki tabloda yer almaktadır: 
Tablo 2.

Psikolojik Esneklik Ölçeğinin Faktör Analizi Sonuçları

\begin{tabular}{|c|c|c|c|c|c|}
\hline & Faktörler & & & & \\
\hline Madde No & $\begin{array}{l}\text { Değer ve Değer } \\
\text { Doğrultusunda } \\
\text { Davranış }\end{array}$ & An'da Olma & Kabul & $\begin{array}{l}\text { Bağlamsal } \\
\text { Benlik }\end{array}$ & Ayrışma \\
\hline 31 & .78 & & & & \\
\hline 35 & .74 & & & & \\
\hline 32 & .71 & & & & \\
\hline 28 & .69 & & & & \\
\hline 30 & .68 & & & & \\
\hline 33 & .68 & & & & \\
\hline 36 & .66 & & & & \\
\hline 29 & .63 & & & & \\
\hline 34 & .60 & & & & \\
\hline 27 & .49 & & & & \\
\hline 22 & & .76 & & & \\
\hline 19 & & .71 & & & \\
\hline 20 & & .68 & & & \\
\hline 21 & & .62 & & & \\
\hline 18 & & .58 & & & \\
\hline 14 & & .57 & & & \\
\hline 23 & & .55 & & & \\
\hline 3 & & & .73 & & \\
\hline 5 & & & .72 & & \\
\hline 4 & & & .65 & & \\
\hline 7 & & & .62 & & \\
\hline 2 & & & .55 & & \\
\hline 10 & & & & .81 & \\
\hline 9 & & & & .70 & \\
\hline 12 & & & & .65 & \\
\hline 16 & & & & & .81 \\
\hline 17 & & & & & .70 \\
\hline 15 & & & & & .47 \\
\hline
\end{tabular}

Tablo 1'de de görüldüğü gibi açımlayıcı faktör analizine göre ölçek maddelerinin faktör yükleri .47 ile .81 arasında değişmektedir.Faktör isimleri ise kuramsal çerçeve göz önünde bulundurularak ve maddelere karşıllk gelmesi ile belirlenmiştir.Değerler ve değer doğrultusunda davranış boyutu kişinin hayatına yön verebilen kuralların ve ilkelerin varlığı ile bu ilkelere uyumlu olacak şekilde davranış sergilemesidir.27, 28, 29, 30, 31, 32, 33, 34, 35 ve 36.maddeler bu yapıyla ilişkili olduğundan 1. boyut bu şekilde isimlendirilmiştir (Örneğin: Madde 27: Yaşamayı seçtiğim önemli değerlere sahibim). 14, $18,19,20,21,22$ ve 23 numaralı maddeler kişinin geçmiş ya da gelecekle uğraşmak yerine şu anda olabilmesi ve dolayısıyla düşünceleri ile boğuşma içinde olmayıp odaklanabilmesini kapsadığından bu boyut 'An'da Olma' olarak isimlendirilmiştir. Bunu yapamayan kişiler yaşamlarını "otomatik pilot" şeklinde sürdürmektedirler (Örneğin: Madde 18: Ne yaptığımın pek farkında olmadan otomatik hareket ediyormuşum gibi görünür). Kabul boyutu ise bireylerin üzüntü ya da acı veren duygu, düşünce ve anılar ile mücadele etmeyip onlara açık olması ve kabullenebilmesi anlamına geldiğinden bu durumla ilişkili maddeler (2, 3, 4, 5 ve 7) bu şekilde isimlendirilmiştir (Örneğin: Madde 3: Olumsuz duygular hissettiğimde dikkatimi dağıtmaya çalışırım). Bağlamsal benlik ise bireyin benliğini düşüncelerinden uzak tutabilmesi, düşüncelerine bağlanmamasını ve kabullenilebilmesini ifade etmektedir. Bu sebeple 9, 10 ve 12. Maddeler 'Bağlamsal Benlik' alt boyutunu karşılamaktadır (Örneğin: Madde 9: Duygu ve düşüncelerimi değiştirmeksizin, onları olduğu gibi kabullenebilirim.). Son alt boyut olan ayrışma ise kişinin düşüncelerinden uzak durabilmesi ve aklına gelen düşüncelerle mücadele içinde olması yerine onları önünden geçen araba gibi izlemesi anlamına geldiğinden 15, 16 ve 17.maddeler bu alt boyuta 
dahil edilmiştir (Örneğin: Madde 16: Düşünceler sadece düşüncelerdir, yaptıklarımı kontrol edemezler.).

\section{Güvenirlik çalışması}

Uyarlama çalışması yapılan 'Psikolojik Esneklik Ölçeği'nin Cronbach Alfa katsayısı .79 olarak hesaplanmıştır.Değer ve değer doğrultusunda davranış, an'da olma, kabul, bağlamsal benlik ve ayrışma alt boyutlarına ilişkin güvenirlik analizi sonuçları Tablo 3'te gösterilmektedir.

Tablo 3.

Psikolojik Esneklik Ölçeğinin Alt Boyutlarına İlişkin Güvenirlik Analizi Sonuçları

\begin{tabular}{lll}
\hline Ölçek Boyutları & Madde Sayısı & Cronbach Alfa Katsayısı \\
\hline Değer ve Değer Doğrultusuna Davranış & 10 madde & .84 \\
An'da Olma & 7 madde & .60 \\
Kabul & 5 madde & .72 \\
Bağlamsal Benlik & 3 madde & .73 \\
Ayrışma & 3 madde & .59 \\
\hline
\end{tabular}

Kayış’ın (2010) Cronbach Alfa değerlerine ilişkin yaptığı sınıflamaya göre .60 ile .80 arasındaki değer ölçeğin güvenilir olduğunun göstergesidir. Bu bilgiye göre ölçeğin güvenilir olduğu söylenebilir.

\section{Tartışma, Sonuç ve Öneriler}

$\mathrm{Bu}$ araştırmanın amacı Francis, Dawson ve Golijani-Moghaddam (2016) tarafından geliştirilen Psikolojik Esneklik Ölçeği'nin psikometrik özelliklerini araştırmaktır.Bu amaç doğrultusunda ölçeğin ileri çevirme çalışması yapıldıktan hemen sonra araştırmacılar ve Türkçe dil uzmanı tarafindan madde çevirileri değerlendirlmiştir.Maddelerin anlaşılırlığı için 3 bireyle yapılan çalışmadan sonra Psikolojik Danışmanlık ve Rehberlik alanı ile dil bilim uzmanlarından değerlendirmeleri istenmiştir.Uzmanlardan gelen dönütler neticesinde ölçeğin son hali ile veriler toplanıp analiz edilmiştir.Dilsel uygunluğuna ilişkin kapsam geçerlik oranları 0,529 ile 1 puan arasında değişmekte iken kültürel uygunluğa ilişkin kapsam geçerlik oranları da 0,765 ile 1 puan arasında değişmektedir. Minumum değer (KGO>.42) göz önünde bulundurulduğunda 36 madde hem dilsel hem de kültürel uygunluk bakımından istatistiksel olarak anlamlı olduğu sonucu elde edilmiştir. Madde 25 ise kültürel olarak uygun olmasına rağmen dilsel olarak $(\mathrm{KGO}=0,294)$ uygun olmadığından çıkarılmışırı.

Yapılan uyarlama çalışmasında ölçek yapının \%60'ını açıkladığı sonucuna ulaşılmıştır. Orjinal ölçekte ise ölçek yapının \%55'ini açıklamaktadır.Bu da çalışmada istenilen sonuca ulaşıldığı ve Türk kültüründe de kullanımının uygun olduğu sonucuna ulaşılabilir.Bu araştırmanın KMO değeri .78 iken orjinal ölçeğin KMO değeri .91'dir.

Francis, Dawson ve Golijani-Moghaddam (2016) tarafından geliştirilen Psikolojik Esneklik Ölçeği 310 katılımcıdan elde edilen veriler ile faktör analizi yapılmıştır. Yirmi üç maddeden ve üç faktörden oluşan ölçeğin faktör yükleri ise .46 ile .77 arasındadır. Bu çalışmadan elde edilen verilerle yapılan faktör analizi sonucuna göre ölçek 28 maddeden ve beş faktörden oluşmakta ve faktör yükleri .47 ile .81 arasında değişmektedir.

Çalışmada Psikolojik Esneklik Ölçeğinin Cronbach Alfa iç tutarlık katsayısı .79 olarak hesaplanmıştır. Ölçeğin orjinal formunun Cronbach Alfa iç tutarlık katsayısı ise .91'dir. Alt boyutların güvenirliğine bakıldığında ise; değer ve değer doğrultusunda davranış boyutu .84, an' da olma .60, kabul .72 , bağlamsal benlik .73 ve ayrışma .59 'dur. Bu doğrultuda ölçeğin güvenilir olup amaca hizmet edeceği düşünülmektedir.

Orjinal ölçekte yer alan madde 1 ve madde 6 Türk kültüründe işlememiştir. Ancak orjinal ölçekte yer almayan 3, 9, 15, 17, 23 ve 36. maddeler Türkçe formda yer almaktadır. Bu farklılık kültür farklılığından kaynaklanabilir.

Uyarlanan ölçeğin maddelerinin nihai hali ile yeniden numaralandırılmıştır. Değerler ve değerler doğrultusunda davranış $(1,7,9,13,16,19,21,26,27,28)$, an'da olma $(8,14,18,20,22,23$, $25)$, kabul $(2,3,5,6,24)$, bağlamsal benlik $(4,10,12)$ ve ayrışma $(11,15,17)$ olmak üzere beş alt boyutu bulunmaktadır.2, 3, 5, 6, 8, 18, 20, 22, 23, 24 ve 25. maddeler tersten puanlanmaktadır. Ölçekten alınabilecek en düşük puan 28 , en yüksek puan ise 196 'dır. Ölçek maddelerinin değerlendirilmesinde her alt ölçekten alınan yüksek puanlar yüksek psikolojik esnekliği yansıtır. 
Uyarlamanın yapıldığı Psikolojik Esneklik Ölçeği, bireylerin psikolojik esnekliklerini ölçmede öncül olarak kabul edilebilir. Bu sebeple, bundan sonra yapılacak olan çalışmalarda bu kavramla ilişki olabilecek bazı değişkenlerle karşılaştırılabilir. Ölçeğin güvenirlik ve geçerlik çalışmaları farklı yaş ve kültürel gruplarda tekrarının yapılması uygun olabilir. Aynı zamanda ölçeğin güvenirlik ve geçerliğine ilişkin farklı yöntemler kullanılması istatistiksel açıdan zenginlik katabilir.

\section{Kaynaklar}

Aktepe, M. (2016).Bipolar bozukluk hastalarında psikolojik esneklik. (Tıpta uzmanlık tezi). Bakırköy Prof. Dr. Mazhar Osman Ruh Sağlığı ve Sinir Hastalıkları Eğitim ve Araştırma Hastanesi Psikiyatri Kliniği, İstanbul.

Albal, E. (2019). Madde bă̆ımlılarında şema ve psikolojik esneklik yaklaşımlarının madde bağımlılı̆̆ı şiddetine etkisi. (Doktora tezi). İstanbul Üniversitesi Cerrahpaşa Lisansüstü Eğitim Enstitüsü, İstanbul.

Büyüköztürk, Ş. (2007). Veri analizi el kitabı. Ankara: Pegema yayıncılık.

Çokluk, Ö., Şekercioğlu, G. ve Büyüköztürk, Ş. (2014). Sosyal bilimler için çok değişkenli istatistik: SPSS ve LISREL uygulamaları. Ankara: Pegem Akademi Yayıncılık.

Francis, A. W., Dawson, D. L. ve Golijani-Moghaddam, N. (2016). The development and validation of the Comprehensive assessment of Acceptance and Commitment Therapy processes (CompACT). Journal of Contextual Behavioral Science. 5, 134-145.

Frankl, V. E. (2013). Insanın anlam arayışı (S. Budak, Çev.). İstanbul: Okuyan Us Yayınları.

Gillanders, D. T., Bolderston, H., Bond, F. W., Dempster, M., Flaxman, P. E., Campbell, L. ve diğerleri (2014). The Development and Initial Validation of the Cognitive Fusion Questionnaire. Behaviour Therapy, 45(1), 83-101.

Gün, N. (2007). İçimizdeki zaman, duyguların simyası. İstanbul: Kuraldış1 Yayınları.

Hall, E. O. C., Wilson, M. E. ve Frankenfield, J. A. (2003). Translation and restandardization of an instrument: The early infant temperament questionnaire. Journal of Advanced Nursing, 42(2), 159-168.

Hambleton, R. K. ve Patsula, L. (1999). Increasing the validity of adapted tests: Myths to be avoided and guidelines for improving test adaptation practices. Journal of Applied Testing Technology, 1(1), 1-30.

Harris, R. (2009). ACT made simple: an easy-to-read primer on Acceptance and Commitment Therapy. New Harbinger Publication. 9 (13), 26-30.

Hayes, C. (2004). Acceptance and Commitment Therapy, relational frame theory, and the third wave of behavioral and cognitive therapies. Behavior Therapy, 35(4), 639-665.

Hayes, S. C., Levin, M. E., Plumb-Vilardaga, J., Villatte, J. L. ve Pistorello, J. (2013). Acceptance And Commitment Therapy and contextual behavioral science: examining the progress of a distinctive model of behavioral and cognitive therapy. Behavior Therapy, 44(2), 180-198.

Kayış, A. (2010). Güvenirlik Analizi. Ş. Kalaycı (Yay. haz). SPSS Uygulamalı Çok Değişkenli Istatistik Teknikleri içinde (ss. 403-419). Ankara: Asil Yayıncılık.

Koçak, R. (2002). Aleksitimi: kuramsal çerçeve tedavi yaklaşımları ve ilgili araştırmalar. Ankara Üniversitesi Eğitim Bilimleri Fakültesi Dergisi, 35(1-2), 183-212.

Luoma, J. B., Hayes, S. C. ve Walser, R. D. (2010). Learning ACT: An Acceptance \& Commitment Therapy skills-training manual for therapists. New Harbinger Publications, 60, 549-552.

Terzi, Ş. ve Ergüner-Tekinalp, B. (2013). Psikolojik danışmada güncel yaklaşımlar. Ankara: PegemAkademi.

Veneziano, L. ve Hooper, J. (1997). A method for quantifying content validity of health-related questionnaires. American Journal of Health Behavior, 21(1), 67-70.

Wong, P. T. (2015). Meaning therapy: assessments and interventions. Existential Analysis: Journal of the Society for Existential Analysis, 26(1), 154-161.

Yavuz, F., Iskin, M., Ulusoy, S., Esen, F. B. ve Burhan, H. S. (2014). Turkish Version of AAQ-II: Preliminary analysis of reliability and validity. ACBS Annual World Conference XII. 17-22 June, MN, Minneapolis.

Yavuz, F. K. (2015). Kabul ve kararlılık terapisi: Genel bir bakış. Türkiye Klinikleri Psikiyatri Özel. $8(2), 21-28$. 


\section{Extended Abstract}

\section{Introduction}

In the Acceptance and Commitment approach, it is emphasized that regardless of what is happening now, individuals should accept it as it is in the face of boredom and pain and embrace life by being aware of these experiences (Terzi \& Tekinalp, 2013). Mental and emotional acceptances, which integra te life with positive and negative aspects as a whole, increase the individual's personal strength against the uncontrollable sides of life (Wong, 2015). One of the basic concepts of the Acceptance and Stability approach and the concept that satisfies these narratives is "psychological flexibility (Yavuz, 2015).

Psychological flexibility is that the individual is not obsessed with the past and the future, but comes into contact with the present and performs behaviors in accordance with the values determined. Psychological flexibility has 6 dimensions: Acceptance, Cognitive decomposition, Getting in contact with the present moment, Contextual self, Values and Behaviors in the values (Luoma, Hayes \& Walser, 2010).

When the literature was examined, there was no developed or adapted scale examining the structure in a single way regarding the concept of psychological flexibility. However, there are studies in which individuals' psychological flexibility is measured using scales such as Acceptance Action Form (Yavuz, Iskin, Ulusoy, Esen \& Burhan, 2014), Freiburg Self-Inventory (Aktepe, 2016), and Cognitive Fusion Scale (Gillanders et al. 2014). Therefore, the aim of this study is to adapt the Psychological Flexibility Scale to Turkish culture.

\section{Method}

The authors were asked to submit a trial form with the idea that the items that could be processed in Turkish culture might be different. For this reason, a trial form consisting of 37 items was sent. The English form of the scale was translated into Turkish by three linguists who speak English and Turkish well and six experts in Guidance and Psychological Counseling. The translations were re-examined by two experts after the collection and finally, the comprehensibility of the items and the appropriateness of the sentence structures were finalized by taking the opinion of a Turkish language expert. Expert evaluation form was prepared for language and cultural validity. The relevant form was given to 18 different experts and they were asked to rank between 1 and 5 according to language suitability and cultural suitability.

After the linguistic and cultural equivalence study, the scale was applied to 310 adult individuals. The application lasted approximately 10 minutes. Exploratory factor analysis was performed to test the construct validity of the scale. Cronbach's alpha coefficient was calculated for reliability analysis. The data were analyzed using SPSS 22 and Excell programs.

\section{Result and Discussion}

When the content validity ratio minimum value (.42) was taken into consideration, it was found that Article 25 was considered culturally appropriate $(\mathrm{KGO}=0.75)$, and it was found to be non-linguistic $(\mathrm{KGO}=0.294)$. When the relevant item was omitted, the content validity rates of the remaining 36 items ranged from 0.529 to 1 point; coverage validity rates for cultural suitability range from 0.765 to 1 point. Accordingly, 36 items were found to be statistically significant in terms of both linguistic and cultural relevance. Exploratory factor analysis was performed on these 36 items. Kaiser-MeyerOlkin (KMO) value derived from exploratory analysis was found to be 0.789 . The results of exploratory factor analysis demonstrated that 28 items loaded on five factor. The amount of total variance explained byfactors was $60 \%$. Factor loads of the scale items ranged from. 47 to .81 .Factor names were determined by considering the theoretical framework and corresponding to the items. According to the results obtained from this adaptation study, the final version of the scale consists of 28 items and five factors, values and behaviors, getting in contact with the present moment, acceptance, cognitive decomposition, Contextual self. The Cronbach's alpha coefficient of the Psychological Flexibility Scale was calculated as. 79. The reliability of the sub-dimensions ranged from .59 to .84 . Accordingly, the scale is believed to be reliable and serve the purpose.Items $2,3,5,6,8,18,20,22,23,24$ and 25 are scored in reverse. The lowest score that can be obtained from the scale is 28 and the highest score is 196. High scores obtained from each subscale in the evaluation of scale items reflect high psychological flexibility. The Psychological Flexibility Scale, which is adapted, can be considered as a precursor for measuring the psychological 
flexibility of individuals. For this reason, it can be compared with some variables that may be related to this concept in the studies that will be done after this.

\section{Psikolojik Esneklik Ölceği}

Aşağıda psikolojik esneklik düzeyinizi ölçmeye ilişkin ifadeler yer almaktadır.Sizden, kendi yaşantınızı dikkate alarak aşağıdaki ifadeleri değerlendirmeniz istenmektedir.Her bir maddeye katılma durumunuza göre7 aralıklı ölçek üzerinde, ilgili rakam üzerine çarpı (X) koyarak gösteriniz.

\begin{tabular}{|c|c|c|c|c|c|c|c|c|}
\hline & $\begin{array}{l}\text { Hiç Tamamen } \\
\text { Katılmıyorum Katıllyorum } \\
\text { 1--------2--------3---------4---------5--------6--------7 }\end{array}$ & 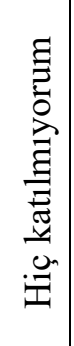 & & & & & & 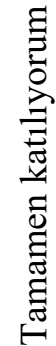 \\
\hline 1. & $\begin{array}{l}\text { Benim için neyin önemli olduğunu ve hayatımda gelmek } \\
\text { istediğim noktayı biliyorum. }\end{array}$ & 1 & 2 & 3 & 4 & 5 & 6 & 7 \\
\hline 2. & $\begin{array}{l}\text { Duygu ve düşüncelerin ortaya çıkmasını engellemek için bir } \\
\text { şeylerle meşgul olmaya çalışırım. }\end{array}$ & 1 & 2 & 3 & 4 & 5 & 6 & 7 \\
\hline 3. & $\begin{array}{l}\text { Olumsuz duygular hissettiğimde dikkatimi dağıtmaya } \\
\text { çalışırım. }\end{array}$ & 1 & 2 & 3 & 4 & 5 & 6 & 7 \\
\hline 4. & $\begin{array}{l}\text { Duygu ve düşüncelerimi değiştirmeksizin, onları olduğu } \\
\text { gibi kabullenebilirim. }\end{array}$ & 1 & 2 & 3 & 4 & 5 & 6 & 7 \\
\hline 5. & $\begin{array}{l}\text { Zorlayıcı duygu, düşünce veya hisleri ortaya çıkarabilecek } \\
\text { durumlardan kaçınmaya çalışırım. }\end{array}$ & 1 & 2 & 3 & 4 & 5 & 6 & 7 \\
\hline 6. & $\begin{array}{l}\text { Üzüntü verici duyguları uzak tutmak için elimden geleni } \\
\text { yaparım. }\end{array}$ & 1 & 2 & 3 & 4 & 5 & 6 & 7 \\
\hline 7. & $\begin{array}{l}\text { Stresli olsa bile, tercihlerimi benim için neyin önemli } \\
\text { olduğuna dayanarak yaparım. }\end{array}$ & 1 & 2 & 3 & 4 & 5 & 6 & 7 \\
\hline 8. & $\begin{array}{l}\text { İş veya görevlerimi, ne yaptığımın farkında olmaksızın, } \\
\text { otomatik bir şekilde yaparım. }\end{array}$ & 1 & 2 & 3 & 4 & 5 & 6 & 7 \\
\hline 9. & Yaşamayı seçtiğim önemli değerlere sahibim. & 1 & 2 & 3 & 4 & 5 & 6 & 7 \\
\hline 10. & $\begin{array}{l}\text { Duygu ve düşüncelerimi kontrol etmek yada onlardan } \\
\text { kaçınmak yerine, onları olduğu gibi kabul edebilirim. }\end{array}$ & 1 & 2 & 3 & 4 & 5 & 6 & 7 \\
\hline 11. & $\begin{array}{l}\text { Düşünceler sadece düşüncelerdir- yaptıklarımı } \\
\text { kontrol etmezler. }\end{array}$ & 1 & 2 & 3 & 4 & 5 & 6 & 7 \\
\hline 12. & $\begin{array}{l}\text { Aklıma gelen düşünce, duygu ve hisler ne olursa olsun, } \\
\text { onları değiştirmeden ve onlara karşı çıkmadan tam anlamıyla } \\
\text { deneyimlemeye razıyım. }\end{array}$ & 1 & 2 & 3 & 4 & 5 & 6 & 7 \\
\hline 13. & Kişisel değerlerim doğrultusunda hareket ederim. & 1 & 2 & 3 & 4 & 5 & 6 & 7 \\
\hline 14. & $\begin{array}{l}\text { Düşüncelerime öyle takılırım ki en çok yapmak istediğim } \\
\text { şeyleri yapamam. }\end{array}$ & 1 & 2 & 3 & 4 & 5 & 6 & 7 \\
\hline 15. & $\begin{array}{l}\text { Düşüncelerimin, yapmak istediğim şeyleri engellemesine } \\
\text { izin vermem. }\end{array}$ & 1 & 2 & 3 & 4 & 5 & 6 & 7 \\
\hline 16. & $\begin{array}{l}\text { Yapmas1 zor olsa bile, benim için anlamlı olan şeylerin } \\
\text { sorumluluğunu alırım. }\end{array}$ & 1 & 2 & 3 & 4 & 5 & 6 & 7 \\
\hline
\end{tabular}




\begin{tabular}{|c|c|c|c|c|c|c|c|c|}
\hline 17. & $\begin{array}{l}\text { Kendim hakkındaki bir düşüncemetam olarak uymak } \\
\text { zorunda değilim. }\end{array}$ & 1 & 2 & 3 & 4 & 5 & 6 & 7 \\
\hline 18. & $\begin{array}{l}\text { Ne yaptığımın pek farkında olmadan otomatik hareket } \\
\text { ediyormuşum gibi görünür. }\end{array}$ & 1 & 2 & 3 & 4 & 5 & 6 & 7 \\
\hline 19. & $\begin{array}{l}\text { Hayatta benim için gerçekten önemli olan şeyleri belirler ve } \\
\text { onların peşinden giderim. }\end{array}$ & 1 & 2 & 3 & 4 & 5 & 6 & 7 \\
\hline 20. & $\begin{array}{l}\text { Benim için anlamlı olan etkinlikleri çok dikkatimi } \\
\text { vermeden aceleyle yaparım. }\end{array}$ & 1 & 2 & 3 & 4 & 5 & 6 & 7 \\
\hline 21. & $\begin{array}{l}\text { Bir şey benim için önemli ise onu yapmaya devam } \\
\text { edebilirim. }\end{array}$ & 1 & 2 & 3 & 4 & 5 & 6 & 7 \\
\hline 22. & Şu anda yaşananlara odaklanmakta zorlanırım. & 1 & 2 & 3 & 4 & 5 & 6 & 7 \\
\hline 23. & $\begin{array}{l}\text { Geçmiş ya da gelecek ile çok meşgul olduğumdan, } \\
\text { kendimi şu an olanları kaçırırken bulurum. }\end{array}$ & 1 & 2 & 3 & 4 & 5 & 6 & 7 \\
\hline 24. & $\begin{array}{l}\text { En büyük hedeflerimden biri bana acı veren duygularımdan } \\
\text { kurtulmaktır. }\end{array}$ & 1 & 2 & 3 & 4 & 5 & 6 & 7 \\
\hline 25. & $\begin{array}{l}\text { Benim için oldukça önemli olsalarda, kendimi, o işi } \\
\text { dikkatimi vermeden yaparken bulurum. }\end{array}$ & 1 & 2 & 3 & 4 & 5 & 6 & 7 \\
\hline 26. & Değerlerim, davranışlarıma tamamıyla yansır. & 1 & 2 & 3 & 4 & 5 & 6 & 7 \\
\hline 27. & $\begin{array}{l}\text { İlerleme yavaş olsa bile, zaman gerektiren uzun vadeli } \\
\text { planlarıma sadık kalabilirim. }\end{array}$ & 1 & 2 & 3 & 4 & 5 & 6 & 7 \\
\hline 28. & $\begin{array}{l}\text { Hayatımı nasıl yaşamak istediğimle uyumlu bir şekilde } \\
\text { hareket ederim. }\end{array}$ & 1 & 2 & 3 & 4 & 5 & 6 & 7 \\
\hline
\end{tabular}

